\title{
PENGARUH WORK LIFE BALANCE DAN DISIPLIN KERJA TERHADAP KINERJA KARYAWAN DIMASA WORK FROM HOME PADA KANTOR KEMENTERIAN AGAMA KABUPATEN INDRAMAYU
}

\author{
Dwi Meli Noviani \\ Universitas Budi Luhur Jakarta, Indonesia \\ Email: dwimelinoviani@gmail.com
}

\begin{abstract}
INFO ARTIKEL ABSTRAK
Diterima

25 Oktober 2021

Direvisi

05 November 2021

Disetujui

15 November 2021

Kata Kunci:

work life balance;

disiplin

kerja; kinerja

pegawai

Penelitian ini bertujuan untuk mengetahui dan menganalisis pengaruh variabel work life balance dan disiplin kerja terhadap kinerja pegawai pada Kantor Kementerian Agama Kabupaten Indramayu. Teknik pengambilan sampel menggunakan sampel jenuh yaitu seluruh jumlah populasi dan didapatkan 52 pegawai di Kantor Kementerian Agama Kabupaten Indramayu. Analisis data menggunakan uji regresi berganda, hipotesis menggunakan uji t (uji parsial) dan uji simultan (uji F), sedangkan pengolahan data menggunakan SPSS 20. Hasil penelitian disimpulkan terdapat pengaruh positif dan signifikan antara variabel work life balance dan disiplin kerja terhadap kinerja pegawai pada Kantor Kementerian Agama Kabupaten Indramayu. Secara simultan work life balance dan disiplin kerja berpengaruh signifikan terhadap kinerja pegawai Kantor Kementerian Agama Kabupaten Indramayu.
\end{abstract}

Keywords: work life balance; work discipline; employees performance

\section{ABSTRACT}

This study aims to determine and analyze the affect of work life balance and work discipline variables on employee performance at Office of the Ministry of Religious Affairs of Indramayu Regency. The sampling technique used as saturated samples, namely the the entire population and obtained 52 respondents at Ministry of Religious Affairs of Indramayu Regency. Analysis using multiple regression test, and hypotesis using t test (patrial test) and simultaneous test ( $F$ test), while data processing using SPSS 20. The results of the study concluded that there was a positive and significant effect between work life balance and work discipline variables on employee performance at Ministry of Religious Affairs of Indramayu Regency. Simultaneously work life balance and work discipline have a significant effect on employees performance at Office of the Ministry of Religious Affairs of Indramayu Regency.

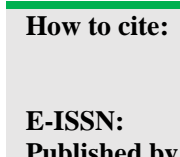

Published by:
Noviani, D. M. (2021) Pengaruh Work Life Balance dan Disiplin Kerja Terhadap Kinerja Karyawan Dimasa Work From Home pada Kantor Kementerian Agama Kabupaten Indramayu. Jurnal Syntax Admiration 2(11). https://doi.org/10.46799/jsa.v2i11.341 2722-5356

Ridwan Institute 


\section{Pendahuluan}

Pandemi covid-19 berdampak signifikan terhadap semua aspek kehidupan, untuk tetap survive selama masa pandemi semua kegiatan harus dilakukan dengan cara-cara baru yaitu menerapkan protokol kesehatan. Pelayanan masyarakat harus tetap berjalan sehingga selama pandemi lembaga negara menerapkan sistem kerja work from home (WFH), langkah ini adalah salah satu cara melakukan kegiatan semasa pandemi covid19. Tetapi dalam prakteknya kualitas pelayanan di masa pandemi mengalami beberapa permasalahan, salah satunya yang dikatakan oleh (Rorong, 2020) dalam penelitiannya yang menyebutkan bahwa di masa pandemi kualitas pelayanan publik yakni di Kecamatan Ratahan Kabupaten Minahasa Tenggara mengalami penurunan kualitas, tingkat disiplin pegawai rendah bahkan sering terjadi aparat pegawai bersangkutan tidak ada ditempat. (Kurdi, 2020) juga mengatakan hal yang sama bahwa pada masa pandemi permasalahan yang timbul adalah sarana dan prasarana serta kualitas dari sumber daya manusianya.

Kementerian Agama Kabupaten Indramayu merespon tantangan kerja dimasa pandemi Covid-19 dengan menerapkan WFH. H. Rosidi (wawancara, 25 Mei 2021) Selaku Plt. Kasubbag Tata Usaha mengatakan bahwa "Pada bulan Maret 2020 Kantor Kementerian Agama Kabupaten Indramayu menerapkan sistem WFH dengan tujuan mencegah penyebaran dan penularan Covid-19 di Kantor Kementerian Agama Indramayu". H. Rosidi menerangkan bahwa mekanisme pelaksanaan WFH harus ditaati oleh semua pegawai walaupun pekerjaan sedikit sulit dilakukan, akan tetapi secara umum proses pelayanan tetap berjalan dan target organisasi tercapai. Sebagaimana dikatakan dalam wawancara bahwa "Pegawai diwajibkan tetap di rumah dan dilarang beraktifitas diluar apalagi keluar daerah, tujuannya untuk kesiapan pegawai tersebut jika pimpinan atau atasan memberikan tugas kepadanya. Dengan adanya $W F H$ pekerjaan pegawai memang agak sedikit terhambat tetapi secara keseluruhan semuanya masih bisa diatasi dengan baik".

Menurut (Setiyawan, 2006) mengatakan bahwa kinerja karyawan adalah penilaian yang ditentukan oleh pihak organiasi dengan melihat hasil atau prestasi kerja karyawan dari segi kualitas maupun kuantitas. Kinerja yang baik adalah kinerja yang sesuai dengan peraturan organisasi dan mendukung tujuan organisasi tersebut. Sehingga organisasi yang meningkatkan kemampuan sumber daya manusianya dikatakan sebagai organisasi yang baik, karena SDM adalah faktor kunci untuk meningkatkan kinerja karyawan.

Menurut (Simanjuntak Payaman, 2005) ada tiga faktor yang mempengaruhi kinerja pegawai atau karyawan yaitu pertama faktor kompetensi individu, faktor dukungan organisasi dan faktor dukungan manajemen. Faktor kompetensi individu merupakan kemampuan dan keterampilan melakukan kerja yang dapat dikelompokan dalam dua golongan yaitu kemampuan dan keterampilan kerja serta motivasi dan etos kerja. Kedua adalah dukungan organisasi, berupa pengorganisasian, penyediaan sarana prasarana kerja, lingkungan kerja yang nyaman, serta kondisi dan syarat kerja yaitu memberikan penjelasan kepada pekerja tentang sasaran tujuan kerja dan cara 
mencapainya. Terakhir adalah dukungan manajemen, dimana kemampuan manajerial dari manajemen atau pimpinan mempengaruhi kinerja suatu perusahaan dan atau setiap pegawainya.

Work life balance merupakan suatu konsep keseimbangan yang mengaitkan tekad ataupun karir dengan kebahagiaan, waktu luang, keluarga, dan pengembangan spiritual. Dengan terdapatnya konsep work life balance ini industri menemukan bonus, sebab kinerja serta kreativitas karyawannya bertambah. Work life balance adalah pelaksanaan aktivitas pekerjaan secara akumulasi baik di dalam organisasi maupun di luar organisasi. Menurut (Singh \& Khanna, 2011) work life balance adalah sebuah konsep menetapkan prioritas tepat antara urusan pekerjaan dan urusan kehidupan.

Disiplin kerja sebagai salah satu syarat yang dibutuhkan untuk meningkatkan kinerja karyawan. (Setiyawan, 2006) mengatakan disiplin adalah keadaan ideal dalam mendukung pelaksanaan tugas sesuai aturan dalam rangka mendukung optimalisasi kerja. Disiplin dapat dikembangkan dalam lingkungan kerja ketika terjadi ada pembagian kerja yang jelas kepada semua karyawan, sehingga setiap karyawan mengetahui tugas dan tanggungjawabnya masing-masing. Sosok pemimpin atau karyawan ideal akan lahir dari disiplin yang baik. (Aritonang, 2005) dalam penelitiannya menemukan bahwa setiap pegawai diharuskan mengetahui tentang segala peraturan dan larangan yang berlaku di perusahaan, dimana disiplin kerja sangat bergantung pada komitmen tinggi dari setiap pegawai.

Penelitian ini dilakukan pada Kantor Kementerian Agama Kabupaten Indramayu merupakan penyelenggara Negara bidang keagamaan yang hirarki kewenangannya langsung ke pemerintah pusat. Selama pandemi Covid-19 Kantor Kementerian Agama Kabupaten Indramayu menerapkan sistem kerja WFH. Namun demikian penerapan WFH tersebut tentu memiliki dampak terhadap kinerja pegawai baik secara positif maupun negatif. Untuk memastikan dampak tersebut dan mengacu pada data-data penelitian diatas, penulis berpandangan akan pentingnya melakukan penelitian tentang kinerja pegawai di Kantor Kementerian Agama Kabupaten Indramayu selama masa pandemi Covid-19, khususnya terkait pengaruh work life balance dan disiplin kerja.

Work Life Balance. Bloombury (2005) dalam (Sarikit, 2017) "Work life balance is a feeling of being in control of your life, being able to exercise choice, and abaout finding an equilibrium between your own needs and those of other, whether at work or at home" (adalah kendali seseorang dalam kehidupan keluarga dan pekerjaan, kemampuan menyeimbangkan antara tanggung jawab kerja dan di luar pekerjaan, menemukan keseimbangan antara kebutuhan sendiri dan kebutuhan orang lain, baik di tempat kerja maupun di rumah). (Mathis, 2011) dalam (Sarikit, 2017) mengatakan "work life balance: balancing their work and personal lives". Begitu juga yang dikatakan oleh (McShane \& Von Glinow, 2010) dalam (Sarikit, 2017) bahwa yang disebut work life balance adalah kemampuan seseorang menyeimbangkan antara tuntutan pekerjaan dengan kebutuhan pribadi dan keluarganya. Keseimbangan yang dimaksud tersebut diidentifikasi melalui beberapa indikator, sebagaimana dikatakan oleh Greenhaus, (Greenhaus et al., 2003) dalam (Nugraha, 2019) yaitu time balance 
atau keseimbangan waktu, involvement balance atau keseimbangan keterlibatan dan satisfaction balance atau keseimbangan kepuasan.

Disiplin Kerja. Devis dalam (Mangkunegara, 2011) mengatakan disiplin kerja adalah pelaksanaan manajemen untuk memperkuat tujuan-tujuan organisasi. (Siagian Sondang, 2002) mengartikan disiplin kerja sebagai peraturan-peraturan yang dibentuk untuk keteraturan dalam bekerja dan meningkatkan pretasi kerja. Menurut (Rivai, 2009) disiplin kerja adalah alat komunikasi yang digunakan oleh pimpinan terhadap karyawan dalam mengubah suatu perilaku dengan tujuan meningkatkan kesadaran dan kesediaan seseorang mengikuti peraturan perusahaan. Singodimejo dalam (Sutrisno, 2013) mengungkapkan indikator disiplin kerja terdiri dari: taat terhadap aturan waktu, taat terhadap aturan perusahaan, taat terhadap aturan perilaku dalam pekerjaan dan taat terhadap peraturan lainnya diperusahaan.

Kinerja (Arshad \& Gondal, 2013) mengartikan kinerja atau performance sebagai deskripsi dari pelaksanaan strategi organisasi dalam pencapaian suatu program kegiatan atau kebijakan untuk mewujudkan sasaran, tujuan visi dan misi organisasi. Kinerja juga berhubungan erat dengan hasil aktivitas individu dalam beberapa periode waktu. Kinerja pegawai atau prestasi kerja memiliki arti sebagai hasil kerja yang dicapai oleh pegawai dalam melaksanakan tugasnya sesuai dengan tanggung jawabnya baik secara kualitas dan kuantitas. AA. Anwar Prabu (Mangkunegara, 2011). Menurut John Miner dalam buku (Lukitaningsih et al., 2009) mengatakan dimensi tolak ukur menilai kinerja ada empat yaitu kualitas, kuantitas, penggunaan waktu dalam bekerja dan kerjasama dengan orang lain dalam bekerja.

\section{Metode Penelitian}

Pendekatan penelitian menggunakan pendekatan deskriptif kuantitaif, adalah metode yang memiliki fungsi untuk mendeskripsikan atau memberi gambaran terhadap objek yang diteliti melalui data atau sampel yang telah terkumpul dengan tanpa melakukan analisis dan membuat kesimpulan secara umum (Sugiyono, 2016).

Populasi (Ananda, 2009) mengatakan populasi disebut sebagai universe yaitu keseluruhan objek yang akan atau ingin diteliti. Populasi dalam penelitian ini adalah seluruh pegawai Kantor Kementerian Agama Kabupaten Indramayu yang berjumlah 52 orang. (Suryani, 2015) maupun (Sugiyono, 2016) mengatakan bahwa apabila jumlah populasi kurang dari 100 orang maka teknik penentuan sampel menggunakan sampel jenuh, yaitu semua anggota populasi dijadikan sampel. Jadi, pada penelitian ini sampel yang digunakan berjumlah 52 pegawai Kantor Kementerian Agama Kabupaten Indramayu.

Teknik pengumpulan data yang digunakan dalam penelitian ini adalah pengumpulan data primer dilakukan melalui kuisioner langsung dengan pegawai di Kantor Kementerian Agama Kabupaten Indramayu dan penelitian data sekunder didapat melalui studi kepustakaan.

Instrumen penelitian yang digunakan dalam penelitian ini adalah wawancara, dengan harapan peneliti mempunyai peluang untuk dapat memahami bagimana 
implementasi WFH di Kementerian Agama Kabupaten Indramayu. (Bambang \& Indriantoro, 2002) mengatakan kuesioner adalah pengumpulan data penelitian yang pada kondisi tertentu memungkinkan peneliti untuk tidak hadir. Akan tetapi melalui kuesioner pertanyaan peneliti dan jawaban responden dapat dikemukakan secara tertulis. Tujuan pembuatan kuesioner untuk memperoleh informasi relavan dari responden.

\section{Hasil dan Pembahasan}

Pengumpulan Data. Penyebaran kuesioner dilakukan kepada 52 pegawai pada Kantor Kementerian Agama Kabupaten Indramayu. Klasifikasi responden dibagi berdasarkan jenis kelamin, umur, pendidikan dan masa kerja.

\section{A. Analisis Deskriptif}

\section{Karakteristik Responden}

Tabel 1

\begin{tabular}{ccccc}
\hline No & Karakteristik & Interval & Responden & Persentase \% \\
\hline 1 & Jenis Kelamin & Laki-laki & 37 orang & $71,2 \%$ \\
\hline & & Perempuan & 15 orang & $28,8 \%$ \\
\hline & & Jumlah & 52 orang & $100 \%$ \\
\hline 2 & Umur & 31-40 Tahun & 10 orang & $19,2 \%$ \\
\hline & & $>41$ Tahun & 42 orang & $80,2 \%$ \\
\hline & & Jumlah & 52 orang & $100 \%$ \\
\hline 3 & Pendidikan & <SMA & 3 orang & $5,8 \%$ \\
\hline & & Diploma & 3 orang & $5,8 \%$ \\
\hline & & Sarjana & 17 orang & $32,7 \%$ \\
\hline & & Magister & 27 orang & $51,9 \%$ \\
\hline & & Doktor & 2 orang & $3,8 \%$ \\
\hline & & Jumlah & 52 orang & $100 \%$ \\
\hline 4 & Masa Kerja & 5-7 Tahun & 5 orang & $9,6 \%$ \\
\hline & & $>7$ Tahun & 47 orang & $90,4 \%$ \\
\hline & & Jumlah & 52 orang & $100 \%$ \\
\hline
\end{tabular}

Sumber: Hasil Penelitian 2021

Hasil penelitian pada Tabel 1 menunjukkan bahwa jumlah responden berdasarkan jenis kelamin terdiri dari 37 orang laki-laki dan 15 orang perempuan, dengan demikian secara persentase jumlah pegawai laki-laki $(71,2 \%)$ lebih banyak dari pada pegawai perempuan $(28,8 \%)$. Jika dilihat dari umur responden, berdasarkan hasil penelitian menunjukkan bahwa umur $>41$ Tahun lebih dominan yaitu 42 orang atau $80,2 \%$, dan sisanya yaitu 10 orang atau 19,2\% berusia antara 31-40 Tahun. Dilihat dari jenjang pendidikan, kebanyakan responden lulusan S2 sebanyak 27 orang atau 51,9\% dan S1 sebanyak 17 orang atau 32,7\%. Terakhir, dilihat dari masa kerja didominasi dengan masa kerja diatas 7 Tahun yaitu 47 orang $(90,4 \%)$.

\section{B. Hasil Uji Asumsi Klasik}

Uji normalitas dilakukan dengan beberapa tahapan yakni Uji Histogram,

Normal P-P Plot Regression Standardized Residual dan Kolmogorov-Smirnov, 
dengan ketentuan dikatakan normal apabila nilai tingkat signifikansi $>0.025$. Hasil uji normalitas pada penelitian ini dapat dilihat sebagaimana berikut:

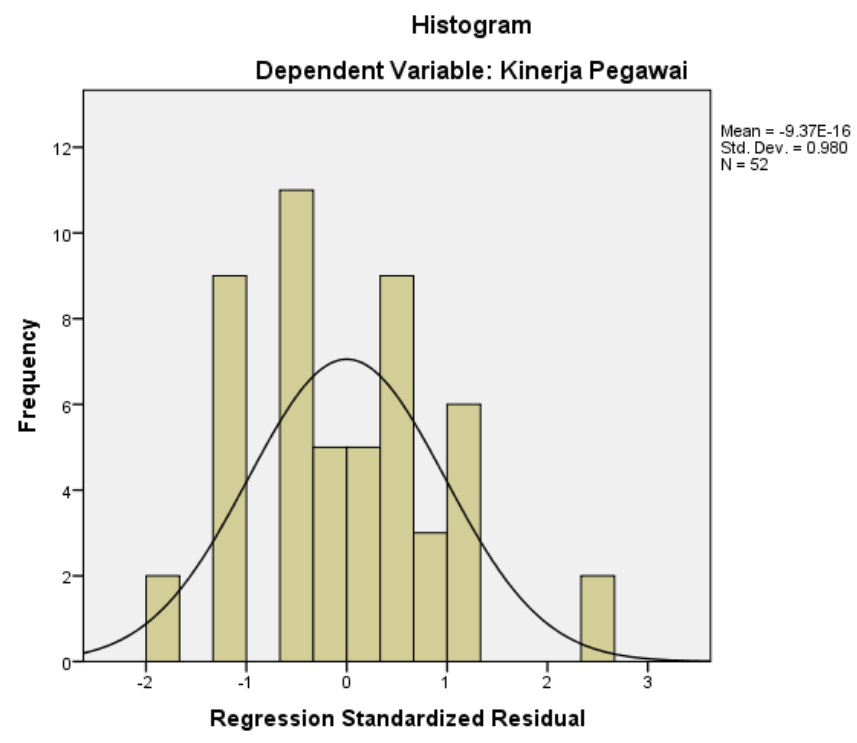

\section{Gambar 1 \\ Histogram}

Sumber: Hasil diolah dari SPSS versi 20.0

Dari hasil uji histogram pada Gambar 1. menunjukkan grafik histogram membentuk pola seperti gunung, artinya hasil pola distribusi tersebut dikatakan normal. Sedangkan untuk uji Normal P-P Plot Regression Standardized Residual hasilnya sebagai berikut:

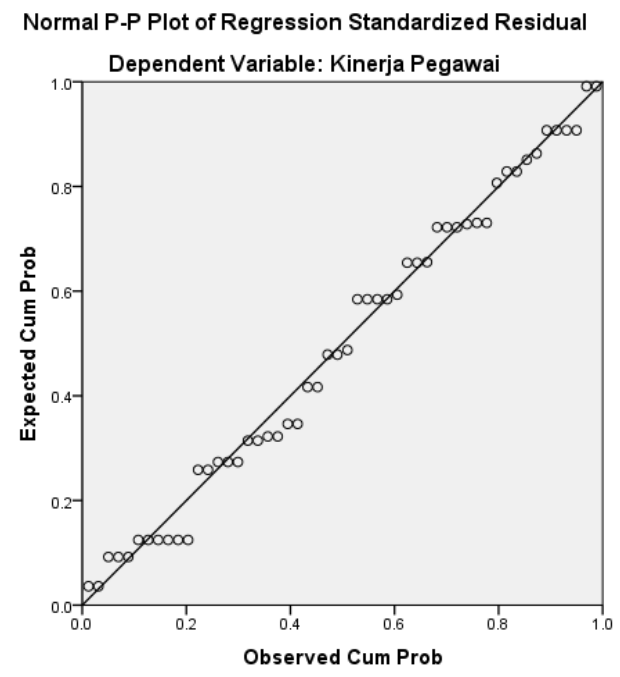

Gambar 2

Normal P-P Plot Regression

Standardized Residual Sumber: Hasil diolah dari SPSS versi 20.0 
Hasil uji Normal P-P Plot Regression Standardized Residual pada gambar 2 menunjukkan penyebaran titik mengikuti alur garis, artinya hasil pola distribusi dikatakan normal. Sedangkan uji normalitas data menggunakan Test of Normality Kolmogorov-Smirnov sebagaimana berikut:

Tabel 2

Uji One-Sample Kolmogorov-Smirnov Test

\begin{tabular}{llr}
\hline & & \multicolumn{1}{c}{$\begin{array}{c}\text { Unstandardized } \\
\text { Residual }\end{array}$} \\
\hline $\mathrm{N}$ & & 52 \\
\hline Normal Parametersa,b & Mean & $0 \mathrm{E}-7$ \\
\cline { 2 - 3 } & Std. Deviation & 2.64094035 \\
\hline Most Extreme Differences & Absolute & .092 \\
\cline { 2 - 3 } & Positive & .092 \\
\cline { 2 - 3 } & Negative & -.067 \\
\hline Kolmogorov-Smirnov $Z$ & & .661 \\
\hline Asymp. Sig. (2-tailed) & & .774 \\
\hline Sumber: Hasil diolah dari SPSS versi 20.0 & \\
\hline
\end{tabular}

Berdasarkan Tabel 2 diketahui nilai Kolmogorov-Smirnov Test sebesar 0,774 > tingkat signifikasi 0,05 maka keputusannya $\mathrm{H} 0$ diterima atau dengan kata lain model regresi linier mempunyai residual atau error normal.

Uji Autokolerasi. Uji autokolerasi dilakukan dengan uji Durbin-Watson (D-W) sebagaimana berikut:

Tabel 3

Uji Autokolerasi

\begin{tabular}{|c|c|c|c|c|c|}
\hline $\begin{array}{c}\text { Mode } \\
1\end{array}$ & $\mathbf{R}$ & $\begin{array}{c}R \\
\text { Square }\end{array}$ & Adjusted R Square & $\begin{array}{l}\text { Std. Error of the } \\
\text { Estimate }\end{array}$ & $\begin{array}{l}\text { Durbin- } \\
\text { Watson }\end{array}$ \\
\hline 1 & $.818^{\mathrm{a}}$ & .670 & .656 & 2.69430 & 1.743 \\
\hline
\end{tabular}

Sumber: Hasil diolah dari SPSS versi 20.0

Berdasarkan hasil pengolahan dengan menggunakan SPSS diketahui nilai Durbin-Watson adalah 1.743. Merujuk pada table-dW, bahwa nilai dL adalah 1,434, selanjutnya untuk mengetahui nilai 4-dL adalah 4 - 1,434 sama dengan 2,566 dan nilai dU adalah 1,677 (4- dU = 4-1,677 =2,323). Jadi disimpulkan bahwa nilai dU adalah 1,677 lebih kecil dari nilai dW sebesar 1,743 dan lebih dari nilai 4-dU adalah 2,323 artinya $\mathrm{H} 0$ diterima dan tidak terjadi autokorelasi.

Uji Multikolinieritas. Hasil uji multikolinieritas sebagai berikut: 
Tabel 4

Uji Multikolinieritas

\begin{tabular}{|c|c|c|c|c|c|c|c|c|}
\hline \multirow{2}{*}{\multicolumn{2}{|c|}{ Model }} & \multicolumn{2}{|c|}{$\begin{array}{c}\text { Unstandardized } \\
\text { Coefficients }\end{array}$} & \multirow{2}{*}{$\begin{array}{c}\begin{array}{c}\text { Standardized } \\
\text { Coefficients }\end{array} \\
\text { Beta }\end{array}$} & \multirow[t]{2}{*}{$\mathbf{T}$} & \multirow[t]{2}{*}{ Sig. } & \multicolumn{2}{|c|}{$\begin{array}{c}\text { Collinearity } \\
\text { Statistics }\end{array}$} \\
\hline & & B & $\begin{array}{c}\text { Std. } \\
\text { Error }\end{array}$ & & & & $\begin{array}{c}\text { Toleran } \\
\text { ce }\end{array}$ & VIF \\
\hline \multirow[t]{3}{*}{1} & $($ Constant $)$ & 1.495 & 3.830 & & .390 & .698 & & \\
\hline & X1_Work Life Balance & .478 & .182 & .418 & 2.623 & .012 & .266 & 3.764 \\
\hline & X2_Disiplin Kerja & .300 & .111 & .431 & 2.707 & .009 & .266 & 3.764 \\
\hline
\end{tabular}

Berdasarkan tabel 4 menunjukkan nilai variant inflation factor (VIF) masingmasing variabel independen memiliki VIF lebih kecil dari 10 dan nilai tolerance lebih besar dari 0,1 sehingga dikatakan bahwa semua variabel independen tidak terjadi multikolinieritas dan dapat digunakan sebagai data penelitian.

Uji Heteroskedastisitas.Uji heteroskedastisitas dilakukan dengan menggunakan uji scatterplot, dengan hasil seperti gambar berikut:

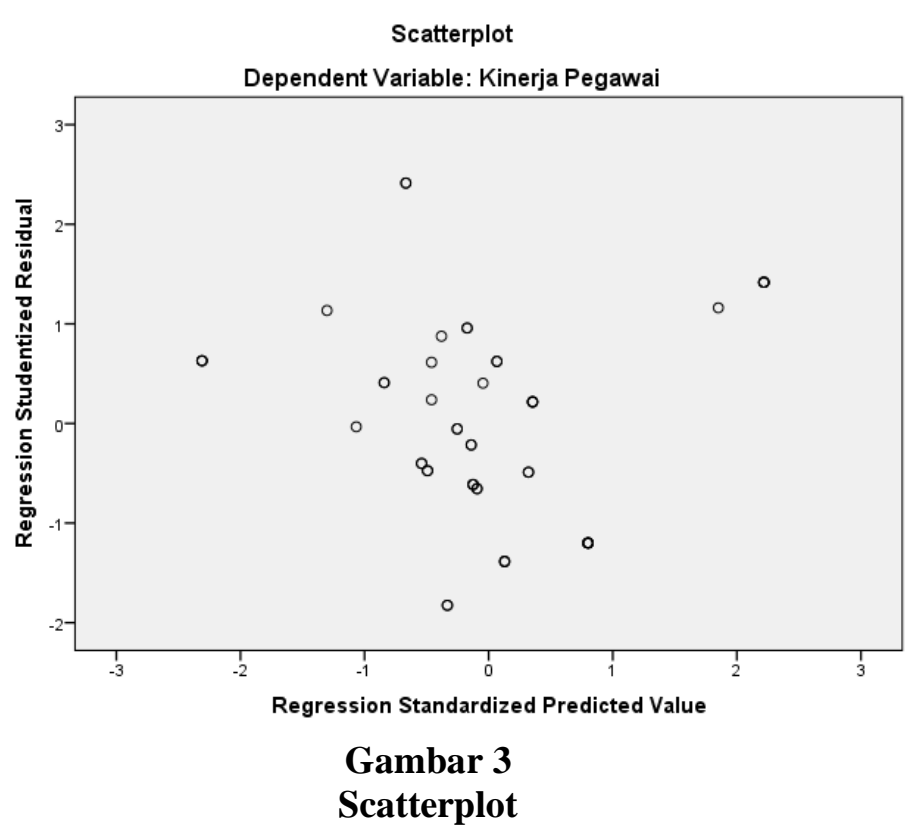

Sumber: Hasil diolah dari SPSS versi 20.0

Berdasarkan tabel 3 dapat dilihat bahwa titik-titik menyebar secara acak, tidak membentuk pola tertentu yang jelas dan tersebar diatas maupun dibawah angka 0 pada sumbu Y. Maka dapat disimpulkan bahwa tidak terjadi heteroskedastisitas pada model regresi ini.

\section{Hasil Koefisiensi Korelasi dan Determinasi}

Analisis Hasil Uji Koefisien Korelasi. Adalah sebagai berikut: 
Tabel 5

Uji Koefisiensi Korelasi

\begin{tabular}{|c|c|c|c|c|}
\hline & & $\begin{array}{c}\text { X1_Work } \\
\text { Life } \\
\text { Balance }\end{array}$ & $\begin{array}{l}\text { X3_Disip } \\
\text { lin Kerja }\end{array}$ & $\underset{\text { Pegawai }}{\text { Y_Kinerja }}$ \\
\hline \multirow{3}{*}{$\begin{array}{l}\mathrm{X} 1 \_ \text {Work } \\
\text { Life } \\
\text { Balance }\end{array}$} & Pearson Correlation & 1 & $.857^{* *}$ & $.788^{* *}$ \\
\hline & Sig. (2-tailed) & & .000 & .000 \\
\hline & $\mathrm{N}$ & 52 & 52 & 52 \\
\hline \multirow{3}{*}{$\begin{array}{l}\text { X2_Disiplin } \\
\text { Kerja }\end{array}$} & Pearson Correlation & $.857^{* *}$ & 1 & $.789^{* *}$ \\
\hline & Sig. (2-tailed) & .000 & & .000 \\
\hline & $\mathrm{N}$ & 52 & 52 & 52 \\
\hline \multirow{3}{*}{$\begin{array}{l}\text { Y_Kinerja } \\
\text { Pegawai }\end{array}$} & Pearson Correlation & $.788^{* *}$ & $.789^{* *}$ & 1 \\
\hline & Sig. (2-tailed) & .000 & .000 & \\
\hline & $\mathrm{N}$ & 52 & 52 & 52 \\
\hline
\end{tabular}

Sumber: Hasil diolah dari SPSS versi 20.0

Hasil pada table 5 dapat dilakukan analisis korelasi masing-masing variabel independent terhadap variabel dependen, sebagai berikut:

a) Hubungan antara work life balance dengan kinerja pegawai terjadi secara signifikan dengan nilai $0,000<0,05$, sedangkan nilai korelasi kuat yakni 0,788 dengan bentuk hubungan positif. Artinya arah hubungan positif disini adalah pada saat work life balance naik maka kinerja pegawai akan naik pula, begitupun sebaliknya.

b) Hubungan antara disiplin kerja dengan kinerja pegawai terjadi secara signifikan dengan nilai $0,000<0,05$, sedangkan nilai korelasi kuat yakni 0,789 dengan bentuk hubungan positif. Artinya arah hubungan positif disini adalah pada saat disiplin kerja naik maka kinerja pegawai akan naik pula, begitupun sebaliknya.

Tabel 6

Uji Koefisiensi Korelasi Parsial

\begin{tabular}{|c|c|c|c|c|c|}
\hline \multicolumn{3}{|c|}{ Control Variables } & \multirow{2}{*}{$\begin{array}{c}\begin{array}{c}\text { Work Life } \\
\text { Balance }\end{array} \\
1.000\end{array}$} & \multirow{2}{*}{$\begin{array}{r}\begin{array}{c}\text { Disiplin } \\
\text { Kerja }\end{array} \\
.857\end{array}$} & \multirow{2}{*}{$\begin{array}{r}\begin{array}{r}\text { Kinerja } \\
\text { Pegawai }\end{array} \\
.788\end{array}$} \\
\hline -none-a & \multirow{3}{*}{$\begin{array}{l}\text { Work Life } \\
\text { Balance }\end{array}$} & Correlation & & & \\
\hline & & Significance (2-tailed) & & .000 & .000 \\
\hline & & $D f$ & 0 & 50 & 50 \\
\hline & \multirow{3}{*}{$\begin{array}{l}\text { Disiplin } \\
\text { Kerja }\end{array}$} & Correlation & .857 & 1.000 & .789 \\
\hline & & Significance (2-tailed) & .000 & . & .000 \\
\hline & & $D f$ & 50 & 0 & 50 \\
\hline & \multirow{3}{*}{$\begin{array}{l}\text { Kinerja } \\
\text { Pegawai }\end{array}$} & Correlation & .788 & .789 & 1.000 \\
\hline & & Significance (2-tailed) & .000 & .000 & \\
\hline & & $D f$ & 50 & 50 & 0 \\
\hline \multirow{6}{*}{$\begin{array}{l}\text { Kinerja } \\
\text { Pegawai }\end{array}$} & \multirow{3}{*}{$\begin{array}{l}\text { Work Life } \\
\text { Balance }\end{array}$} & Correlation & 1.000 & .622 & \\
\hline & & Significance (2-tailed) & 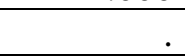 & .000 & \\
\hline & & $D f$ & 0 & 49 & \\
\hline & \multirow{3}{*}{$\begin{array}{l}\text { Disiplin } \\
\text { Kerja }\end{array}$} & Correlation & .622 & 1.000 & \\
\hline & & Significance (2-tailed) & .000 & & \\
\hline & & $D f$ & 49 & 0 & \\
\hline
\end{tabular}

Sumber: Hasil diolah dari SPSS versi 20.0 
Pada tabel 6 output "-none-a" adalah hasil nilai kolerasi sebelum adanya variabel kontrol (kinerja pegawai) antara variabel work life balance dan disiplin kerja. Hasilnya menunjukkan nilai korelasi work life balance dengan disiplin kerja sebesar 0,857 (positif) dengan nilai signifikansi 0,000. Kesimpulannya tanpa adanya variabel kontrol kedua variable memiliki hubungan, dengan nilai korelasi sebesar 0,857 (hubungan sangat kuat). Pada Tabel 9 output kedua "kinerja pegawai" menjelaskan tentang nilai kolerasi antara variabel work life balance dan disiplin kerja setelah adanya kinerja pegawai sebagai variabel kontrol ke dalam analisis. Hasilnya nilai korelasi work life balance dengan disiplin kerja sebesar 0,622 (positif) dengan nilai signifikan 0,000. Kesimpulannya dengan adanya variabel kinerja pegawai sebagai kontrol maka hunungan antara variabel work life balance dengan disiplin kerja terjadi signifikan (nyata), dengan nilai korelasi sebesar 0,622 (kategori hubungan kuat).

Analisis Hasil Uji Koefisien Determinasi. Koefisien determinasi bertujuan untuk mengetahui seberapa besar pengaruh variabel independen dalam menjelaskan variabel dependen.

Tabel 7

Hasil Analisis Uji Koefisien Determinasi

\begin{tabular}{ccccc}
\hline Model & $\mathbf{R}$ & $\boldsymbol{R}$ Square & Adjusted $\boldsymbol{R}$ Square & $\begin{array}{c}\text { Std. Error of the } \\
\text { Estimate }\end{array}$ \\
\hline 1 & $.818^{\mathrm{a}}$ & .670 & .656 & 2.69430 \\
\hline
\end{tabular}

Sumber: Hasil diolah dari SPSS versi 20.0

Berdasarkan hasil uji koefisien determinasi sebagimana tabel 7 didapatkan nilai Adjussted $R$ Square sebesar 0,656, artinya pengaruh variabel independen (X) terhadap variabel dependen (Y) sebesar $65,6 \%$ atau kinerja pegawai dapat dijelaskan oleh work life balance dan disiplin kerja sebesar 65,6\%.

Untuk uji koefisien determinasi masing-masing variabel dapat dilihat pada Tabel dibawah ini:

Tabel 8

Hasil Analisis Uji Koefisien Determinasi Work Life Balance

\begin{tabular}{ccccc}
\hline Model & $\mathbf{R}$ & $\begin{array}{c}\boldsymbol{R} \\
\text { Square }\end{array}$ & Adjusted R Square & $\begin{array}{c}\text { Std. Error of the } \\
\text { Estimate }\end{array}$ \\
\hline 1 & .788 & .620 & .613 & 2.85969 \\
\hline
\end{tabular}

Sumber: Hasil diolah dari SPSS versi 20.0

Tabel 9

Hasil Analisis Uji Koefisien Determinasi Disiplin Kerja

\begin{tabular}{ccccc}
\hline Model & $\mathbf{R}$ & $\begin{array}{c}\boldsymbol{R} \\
\text { Square }\end{array}$ & Adjusted $\boldsymbol{R}$ Square & $\begin{array}{c}\text { Std. Error of the } \\
\text { Estimate }\end{array}$ \\
\hline 1 & .789 & .623 & .616 & 2.84838 \\
\hline
\end{tabular}

Sumber: Hasil diolah dari SPSS versi 20.0 


\section{Analisis Regresi Berganda}

Tabel 10

Analisis Regresi Berganda

\begin{tabular}{|c|c|c|c|c|c|c|c|c|c|c|}
\hline \multirow{2}{*}{ Model } & \multicolumn{2}{|c|}{$\begin{array}{c}\text { Unstandardized } \\
\text { Coefficients }\end{array}$} & \multirow{2}{*}{$\begin{array}{c}\begin{array}{c}\text { Standar } \\
\text { dized } \\
\text { Coeffici } \\
\text { ents }\end{array} \\
\text { Beta }\end{array}$} & \multirow[t]{2}{*}{$T$} & \multirow[t]{2}{*}{$\begin{array}{l}\text { Si } \\
g .\end{array}$} & \multicolumn{3}{|c|}{ Correlations } & \multicolumn{2}{|c|}{$\begin{array}{l}\text { Collinearity } \\
\text { Statistics }\end{array}$} \\
\hline & B & $\begin{array}{l}\text { Std. } \\
\text { Error }\end{array}$ & & & & $\begin{array}{l}\text { Zero- } \\
\text { order }\end{array}$ & $\begin{array}{c}\text { Partia } \\
\quad l\end{array}$ & Part & $\begin{array}{l}\text { Tole } \\
\text { ran } \\
\text { ce }\end{array}$ & VIF \\
\hline 1 (Constant) & 1.495 & 3.830 & & .390 & .698 & & & & & \\
\hline Work Life Balance & .478 & .182 & .418 & 2.623 & .012 & .788 & .351 & .215 & .266 & 3.764 \\
\hline Disiplin Kerja & .300 & .111 & .431 & 2.707 & .009 & .789 & .361 & .222 & .266 & 3.764 \\
\hline
\end{tabular}

Berdasarkan Tabel 11 Persamaan Regresi Dapat Diketahui Sebagai Berikut:

Y_Kinerja Pegawai $=1,495+0,478 \_X 1 \_$Work Life Balance + 0,300_X2_Disiplin Kerja

Persamaan Regresi Diinterprestasikan Sebagai Berikut:

a) Konstanta 1,495: artinya jika tanpa work life balance dan disiplin kerja, maka nilai kinerja pegawai adalah 1,495 .

b) Koefisiensi regresi variabel jika work life balance (X1) sebesar 0,478: artinya jika work life balance bertambah 1 (satu), maka kinerja pegawai akan bertambah sebesar 0,526. Koefisien bernilai positif artinya terjadi pengaruh positif antara variabel independen dengan variabel dependen, semakin naik work life balance semakin naik kinerja pegawai dan sebaliknya.

c) Koefisiensi regresi variabel jika disiplin kerja (X2) sebesar 0,300: artinya jika disiplin kerja bertambah 1 (satu), maka kinerja pegawai akan bertambah sebesar 0,300. Koefisien bernilai positif artinya terjadi pengaruh positif antara variabel independen dengan variabel dependen, semakin naik disiplin kerja semakin naik kinerja pegawai dan sebaliknya.

\section{E. Hasil Uji Hipotesis}

Uji Hipotesis. Uji hipotesis dilakukan dua kali, pertama uji simultan yaitu menguji pengaruh variabel bebas (work life balance dan disiplin kerja) secara bersama-sama terhadap Kinerja Pegawai dengan menggunakan uji F. Kedua, uji parsial dengan menggunakan uji t yaitu untuk menguji pengaruh variabel bebas secara sendiri-sendiri terhadap kinerja pegawai.

Uji f. Pengujian dilakukan dengan membandingkan hasil dari penelitian yaitu nilai signifikan $<0,05$ dan nilai $\mathrm{f}_{\text {hitung }}>\mathrm{f}_{\text {Tabel }}(2,790)$.

Hipotesis:

$\mathrm{HO}=$ Tidak ada pengaruh secara signifikan antara work life balance dan disiplin kerja secara bersama-sama/simultan terhadap kinerja pegawai. 
Pengaruh Work Life Balance dan Disiplin Kerja Terhadap Kinerja Karyawan Dimasa Work From Home pada Kantor Kementerian Agama Kabupaten Indramayu

H1 = Ada pengaruh secara signifikan antara work life balance dan disiplin kerja secara bersama-sama/simultan terhadap kinerja pegawai.

Tabel 12

Hasil Uji F

\begin{tabular}{llccccc}
\hline & Model & Sum of Squares & Df & Mean Square & F & Sig. \\
\hline \multirow{2}{*}{1} & Regression & 720.816 & 2 & 360.408 & 49.648 & $.000^{\mathrm{b}}$ \\
\cline { 2 - 7 } & Residual & 355.703 & 49 & 7.259 & & \\
\cline { 2 - 7 } & Total & 1076.519 & 51 & & & \\
\hline
\end{tabular}

Sumber: Hasil diolah dari SPSS versi 20.0

F. Hasil Uji Hipotesis Pengaruh Work Life Balance dan Disiplin Kerja terhadap Kinerja Karyawan dimasa Work from Home pada Kantor Kementerian Agama Kabupaten Indramayu

Diketahui dari tabel 12 bahwa hasil nilai signifikan $0,000<0,05$ dan nilai $\mathrm{f}$ hitung 49,648 > f Tabel 2,790, artinya bahwa H0 ditolak dan disimpulkan ada pengaruh secara signifikan antara work life balance (X1) dan disiplin kerja (X2) secara simultan atau bersama-sama terhadap kinerja pegawai (Y).

Uji $t$ atau uji parsial. Pengujian dilakukan dengan membandingkan hasil dari penelitian yaitu nilai signifikan $<0,05$ dan nilai $\mathrm{t}_{\text {hitung }}>\mathrm{t}$ Tabel $(2,010)$.

Hipotesis

$\mathrm{H} 0$ = tidak ada pengaruh signifikan antara satu variabel independen (work life balance dan disiplin kerja) terhadap kinerja pegawai.

$\mathrm{H} 1$ = Ada pengaruh signifikan antara satu variabel independen (work life balance dan disiplin kerja) terhadap kinerja pegawai.

Tabel 13

Hasil Uji t

\begin{tabular}{lccccc}
\hline \multirow{2}{*}{ Model } & \multicolumn{2}{c}{$\begin{array}{c}\text { Unstandardized } \\
\text { Coefficients }\end{array}$} & $\begin{array}{c}\text { Standardized } \\
\text { Coefficients }\end{array}$ & T & Sig. \\
\cline { 2 - 6 } & $\mathbf{B}$ & Std. Error & Beta & & \\
\hline 1 (Constant) & 1.495 & 3.830 & & .390 & .698 \\
\hline Work Life Balance & .478 & .182 & .418 & 2.623 & .012 \\
\hline Disiplin Kerja & .300 & .111 & .431 & 2.707 & .009 \\
\hline
\end{tabular}

Sumber: Hasil diolah dari SPSS versi 20.

\section{G. Hasil Uji Hipotesis Pengaruh Work Life Balance terhadap Kinerja Karyawan dimasa Work From Home pada Kantor Kementerian Agama Kabupaten Indramayu}

Berdasarkan tabel 13 diketahui bahwa hasil nilai signifikan variabel work life balance sebesar 0,012 <0,05 dan nilai $\mathrm{t}$ hitung 2,623 $>\mathrm{t}$ Tabel 2,010, artinya bahwa $\mathrm{H} 0$ ditolak dan disimpulkan bahwa variabel work life balance berpengaruh signifikan terhadap kinerja pegawai. Ha ini menunjukan bahwa work life balance yang diterapkan pada Kantor Kementerian Agama Kabupaten Indramayu sudah berjalan dengan baik. 


\section{H. Hasil Uji Hipotesis Pengaruh Disiplin Kerja terhadap Kinerja Karyawan dimasa Work From Home pada Kantor Kementerian Agama Kabupaten Indramayu}

Berdasarkan tabel 13 diketahui bahwa hasil nilai signifikan variabel disiplin kerja sebesar 0,009 <0,05 dan nilai $\mathrm{t}$ hitung 2,707 > t Tabel 2,010, artinya bahwa H0 ditolak dan disimpulkan bahwa variabel disiplin kerja berpengaruh signifikan terhadap kinerja pegawai. Ha ini menunjukan bahwa disiplin kerja yang diterapkan pada Kantor Kementerian Agama Kabupaten Indramayu sudah berjalan dengan baik.

\section{Kesimpulan}

Berdasarkan penelitian hasil ditemukan adanya pengaruh yang signifikan antara variabel work life balance dan disisiplin kerja terhadap kinerja pegawai dimasa work from home pada Kantor Kementerian Agama Kabupaten Indramayu, baik secara simultan maupun bersama-sama.

Tabel 14

Korelasi atau Hubungan

\begin{tabular}{|c|c|}
\hline Nama Variabel & Kinerja Pegawai \\
\hline $\begin{array}{l}\text { Work Life } \\
\text { Balance }\end{array}$ & $\begin{array}{l}\text { Korelasi sebesar } 0,788 \text {, korelasi kuat dan } \\
\text { positif }\end{array}$ \\
\hline Disipiln Kerja & $\begin{array}{l}\text { Korelasi sebesar } 0,789 \text {, korelasi kuat dan } \\
\text { positif }\end{array}$ \\
\hline
\end{tabular}

Tabel 15

Rangkuman Secara Parsial

\begin{tabular}{|c|c|c|c|c|}
\hline $\mathbf{X}$ & $\begin{array}{c}\text { Variabel } \\
\text { Independen }\end{array}$ & Berpengaruh & $\begin{array}{c}\text { Tidak } \\
\text { Berpengaruh }\end{array}$ & $\begin{array}{c}\text { Variabel } \\
\text { Dependen }\end{array}$ \\
\hline $\mathrm{X} 1$ & $\begin{array}{ll}\text { Work } & \text { Life } \\
\text { Balance } & \end{array}$ & $\sqrt{ }$ & & Kinerja Pegawai \\
\hline $\mathrm{X} 2$ & Disipiln Kerja & $\sqrt{ }$ & & Kinerja Pegawai \\
\hline
\end{tabular}

Tabel 16

Rangkuman Secara Simultan

\begin{tabular}{|c|c|c|c|c|}
\hline $\mathbf{X}$ & $\begin{array}{c}\text { Variabel } \\
\text { Independen }\end{array}$ & Berpengaruh & $\begin{array}{c}\text { Tidak } \\
\text { Berpengaruh }\end{array}$ & $\begin{array}{c}\text { Variabel } \\
\text { Dependen }\end{array}$ \\
\hline $\mathrm{X} 1$ & Work Life Balance & $\sqrt{ }$ & & $\begin{array}{l}\text { Kinerja } \\
\text { Pegawai }\end{array}$ \\
\hline $\mathrm{X} 2$ & Disipiln Kerja & $\sqrt{ }$ & & $\begin{array}{l}\text { Kinerja } \\
\text { Pegawai }\end{array}$ \\
\hline
\end{tabular}


Pengaruh Work Life Balance dan Disiplin Kerja Terhadap Kinerja Karyawan Dimasa Work From Home pada Kantor Kementerian Agama Kabupaten Indramayu

\section{BIBLIOGRAFI}

Ananda, R. (2009). Metodologi Peneliti Kuantitif. Bandung: Cita Pustaka Media. Google Scholar

Aritonang, K. T. (2005). Kompensasi kerja, disiplin kerja guru dan kinerja guru SMP kristen BPK Penabur Jakarta. Jurnal Pendidikan Penabur, 4 (4), 1-16. Google Scholar

Arshad, Z., \& Gondal, M. Y. (2013). Impact of working capital management on profitability a case of the Pakistan cement industry. Interdisciplinary Journal of Contemporary Research in Business, 5 (2), 384-390. Google Scholar

Bambang, S., \& Indriantoro, N. (2002). Metode Penelitian Bisnis. Cetakan Kedua, Yogyakarta: Penerbit BFEE UGM. Google Scholar

Greenhaus, J. H., Collins, K. M., \& Shaw, J. D. (2003). The relation between workfamily balance and quality of life. Journal of Vocational Behavior, 63 (3), 510531. Google Scholar

Kurdi, M. (2020). Menggagas Pelayanan Prima di Masa Pandemic Covid-19. Jurnal Lingkar Widyaiswara, 7 (4), 4-9. Google Scholar

Lukitaningsih, E., Wisnusaputra, A., \& Sudarmanto, B. S. A. (2009). Scrining in silico active compound of Pachyrrhizus erosus as antitirosinase on Aspergillus oryzae (computattional study with homology modeling and molecular docking). Majalah Obat Tradisional, 20 (1), 7-15. Google Scholar

Mangkunegara, A. A. A. P. (2011). Manajemen sumber daya manusia perusahaan. Google Scholar

Mathis, R. L. (2011). dan Jackson, (2011). Human Resource Management. Google Scholar

McShane, S., \& Von Glinow, M. A. (2010). Organizational behaviour: Emerging knowledge and practice for the real world. McGraw-Hill/Irwin. Google Scholar

Nugraha, D. (2019). Pengaruh Leader Member Exchange (Lmx) Dan Work Life Balance Terhadap Turnover Intention Karyawan Divisi Produksi Di Pt Mustika Dharmajaya. Agora, 7 (2). Google Scholar

Rivai, V. (2009). Manajemen sumber daya manusia untuk perusahaan: Dari teori ke praktik. Rajawali Pers. Google Scholar

Rorong, M. (2020). Evaluasi Kinerja Pelayanan Publik Pada Masa Pandemi Covid 19 Di Kecamatan Ratahan Kabupaten Minahasa Tenggara. Jurnal Politico, 9 (1). Google Scholar 
Sarikit, M. (2017). Pengaruh work life balance dan keterikatan pegawai terhadap kinerja pegawai fakultas ilmu sosial dan ilmu politik Universitas Indonesia. Jurnal Manajemen Pendidikan, 8 (1), 82-91. Google Scholar

Setiyawan, B. (2006). Waridin. 2006. Pengaruh Disiplin Kerja Karyawan Dan Budaya Organisasi Terhadap Kinerja Di Divisi Radiologi RSUP Dokter Kariadi Semarang. JRBI, 2 (2), 181-198. Google Scholar

Siagian Sondang, P. (2002). Kiat Meningkatkan Produktivitas Kerja. Cetakan Pertama, PT. Rineka Cipta, Jakarta. Google Scholar

Simanjuntak Payaman, J. (2005). Manajemen dan Evaluasi Kinerja. Jakarta: Lembaga Penerbit Fakultas Ekonomi Universitas Indonesia. Google Scholar

Singh, P., \& Khanna, P. (2011). Work-life balance a tool for increased employee productivity and retention. Lachoo Management Journal, 2 (2), 188-206. Google Scholar

Sugiyono, D. (2016). Metode Penelitian Administratif. Google Scholar

Suryani, H. (2015). Metode riset kuantitatif: Teori dan aplikasi pada penelitian bidang manajemen dan ekonomi Islam. Jakarta: Prenada Group. Google Scholar

Sutrisno, E. (2013). Manajemen sumber daya manusia. Google Scholar

\section{Copyright holder:}

Dwi Meli Noviani (2021)

First publication right:

Jurnal Syntax Admiration

This article is licensed under: 